\title{
Germinated brown rice (GBR) reduces the incidence of aberrant crypt foci with the involvement of $\beta$-catenin and COX- 2 in azoxymethane-induced colon cancer in rats
}

\author{
Saiful Yazan Latifah*1,4, Nurdin Armania1', Tan Hern Tze1, Yaacob Azhar'1, Abdul Hadi Nordiana4 , Saad Norazalina², \\ Ithnin Hairuszah³, Moin Saidi1 and Ismail Maznah'1,4
}

\begin{abstract}
Chemoprevention has become an important area in cancer research due to the failure of current therapeutic modalities. Epidemiological and preclinical studies have demonstrated that nutrition plays a vital role in the etiology of cancer. This study was conducted to determine the chemopreventive effects of germinated brown rice (GBR) in rats induced with colon cancer. GBR is brown rice that has been claimed to be richer in nutrients compared to the common white rice. The male Sprague Dawley rats ( 6 weeks of age) were randomly divided into 5 groups: (G1) positive control (with colon cancer, unfed with GBR), (G2) fed with $2.5 \mathrm{~g} / \mathrm{kg}$ of GBR (GBR (g)/weight of rat (kg)), (G3) fed with $5 \mathrm{~g} / \mathrm{kg}$ of GBR, (G4) fed with $10 \mathrm{~g} / \mathrm{kg}$ of GBR and (G5) negative control (without colon cancer, unfed with GBR). GBR was administered orally once daily via gavage after injection of $15 \mathrm{mg} / \mathrm{kg}$ of body weight of azoxymethane (AOM) once a week for two weeks, intraperitonially. After 8 weeks of treatment, animals were sacrificed and colons were removed. Colonic aberrant crypt foci (ACF) were evaluated histopathologically. Total number of ACF and AC, and multicrypt of $A C F$, and the expression of $\beta$-catenin and COX-2 reduced significantly $(p<0.05)$ in all the groups treated with GBR (G2, G3 and G4) compared to the control group (G1). Spearman rank correlation test showed significant positive linear relationship between total $\beta$-catenin and COX-2 score (Spearman's rho $=0.616, p=0.0001$ ). It is demonstrated that GBR inhibits the development of total number of ACF and AC, and multicrypt of ACF, reduces the expression of $\beta$-catenin and COX-2, and thus can be a promising dietary supplement in prevention of colon cancer.
\end{abstract}

\section{Background}

Colon cancer develops through a multistage process that could be recognized at a histopathological level by progression from mucosa to invasive carcinoma. Colorectal cancer is becoming increasingly common in Asian countries while remains the second leading cause of cancer death in the United States. Approximately 110,000 new cases are diagnosed each year [1]. Epidemiological data suggest that diet is a major factor in the etiology of colon cancer [2].

GBR is brown rice, which has been soaked in water for up to a day and has a germ of approximately $1 \mathrm{~mm}$ long.

* Correspondence: latifah@medic.upm.edu.my

1 Department of Biomedical Science, Faculty of Medicine and Health Sciences, Universiti Putra Malaysia, 43400 UPM Serdang, Selangor Malaysia

Full list of author information is available at the end of the article
During germination, nutrients in the brown rice change drastically. Nutrients that increase in content include $\gamma$ amirobutyric acid (GABA), dietary fiber, inositols, ferulic acid, phytic acid, tocotrienols, magnesium, potassium, zinc, $\gamma$-oryzanol, and prolylendopeptidase inhibitor [3]. According to Ken'ichi, germinated brown rice contained more total ferulic acid (126\%), total dietary fiber (145\%), soluble dietary fiber $(120 \%)$ and insoluble dietary fiber (150\%) compared to the brown rice [4]. Aberrant crypt foci (ACF) are a cluster of colorectal crypts with abnormal morphology that was first discovered in mice treated with azoxymethane [5]. In 1991, Prestlow has proposed that aberrant crypt foci in methylene blue-stained of colon as putative preneoplastic lesions that could be found in rodents as well as in human [6]. ACF were identified in rat colon, appearing a few weeks after treatment 
with carcinogen and becoming larger with time, with more marked nuclear atypia or dysplasia [7]. The aberrant crypts stained more darkly, were larger and had a thicker epithelial lining and a larger pericryptal zone than normal crypts [8]. Further investigation had established ACF as biomarkers of cancer risk in azoxymethane (AOM)-treated in rodents [9].

$\beta$-catenin, which was originally a cadherin-binding protein, has recently been proven to function as a transcriptional activator when it formed a complex with members of the $\mathrm{T}$ cell factor ( $\mathrm{Tcf}$ ) family of DNA binding protein $[10,11]$. Activation of the $\beta$-catenin-Tcf pathway results in the accumulation of $\beta$-catenin in the cytosol and nucleus $[11,12]$. Target genes of the $\beta$-catenin-Tcf pathway were determined to be growth-promoting genes, which suggest that $\beta$-catenin-Tcf is an oncogenic pathway. It is also known that $\beta$-catenin levels are regulated by the degradation of the protein through the ubiquitin-proteasome pathway [13]. Mutation in the Adenomatous polyposis coli $(A P C)$ or $\beta$-catenin genes, are associated with majority of human and rat colon tumors $[13,14]$ and were proved to repress the degradation of the protein and generate $\beta$-catenin accumulations [15], which leads to activation of the oncogenic $\beta$-catenin-Tcf pathway. Excessive $\beta$ catenin protein has been shown in many colon cancers of rats and human [13]. Yamada et al. [16] had demonstrated that $\beta$-catenin gene mutations and accumulations of the protein are involved in the initial stage of colon carcinogenesis induced in rats by AOM.

Cyclooxygenase (COX) catalyses the rate limiting step in the conversion of arachidonic acid to prostaglandin $\mathrm{H} 2$ (PGH2), which is further metabolized to form PGD2, PGE2, PGF2 $\alpha$, PGI2, thromboxanes A2 and leukotrienes [17-19]. COX exists in at least two different isoforms COX-1 and COX-2, which have a high degree of structural and enzymatic homology but pharmacologically distinct [20]. COX-2 is an inducible enzyme produced mainly in inflammatory cells, inflammatory sites and colorectal carcinomas [19,21]. $\beta$-catenin-Lef (lymphoid enhancer-binding factor) complex acts as a crucial regulators of COX-2 mRNA, protein and PGE2 expression [22]. It has been demonstrated that the COX-2 5 ' regulatory region contains the consensus Lef- 1 binding motive, thus supporting the hypothesis that COX-2 expression is mediated through Wnt (the name derived from lnt-1 and Drosophila wingless) signalling pathway. In animal studies, COX-2 mRNA and protein level in adenomatous tissue is three fold higher than normal mucosa of the same Min mouse bearing a mutation in the $A P C$ gene and markedly elevated in carcinogen-induced rat colonic tumours $[23,24]$.

Studies have led to the recognition of the importance of COX-2 in colorectal tumorigenesis and in the development of intestinal neoplasms in genetically manipulated animal models, in which overexpression of COX-2 in colon cancer as well as its established cell lines is frequently demonstrated [25]. Tsujii et al. has also demonstrated that COX-2 overexpression enhances neovascularization thus conferring survival advantage of colon cancer cells [26].

Continuous intake of germinated brown rice has been predicted to prevent cancer of colon, but there is no scientific proof on that, as yet [27]. The goal of this study was to determine the chemopreventive properties of germinated brown rice in rat induced with colon cancer.

\section{Materials and methods}

\section{Animals, diets, carcinogen and GBR}

Five-week-old male Sprague Dawley rats were purchased from the Faculty of Veterinary Medicine, UPM. Animal Care and Use Ethic was obtained from the Animal Care and Use Committee (ACUC), Faculty of Medicine and Health Sciences, Universiti Putra Malaysia (ACUC No; UPM/FPSKPADS/FO1-00172). AOM was purchased from Sigma Chemical Company, St. Louis USA. The rats were housed in plastic cages ( 2 rats per cage) with woodchip bedding in a well ventilated room at room temperature, $29-32^{\circ} \mathrm{C}$; $50-60 \%$ relative humidity; 12 hours light and darkness cycle. Hygienic conditions were maintained by weekly changes of the woodchip beds. GBR was kindly supplied by the Laboratory of Molecular Biomedicine, Institute of Bioscience, Universiti Putra Malaysia. Briefly, GBR was soaked at $32^{\circ} \mathrm{C}$ for 24 hours until germinated. Subsequently, GBR was ground using Rotary type grinding and pulverizing machines (RT-34) to produce powder. The GBR powder was dissolved in distilled water according to the dosage/treatment.

\section{Experimental procedures}

Following a one week of acclimatization, the male Sprague Dawley rats were divided into five groups $(\mathrm{n}=$ 10 ), which were (G1) positive control (with colon cancer, unfed with GBR), (G2) fed with $2.5 \mathrm{~g} / \mathrm{kg}$ of GBR (GBR (g)/ weight of rat (kg), (G3) fed with $5 \mathrm{~g} / \mathrm{kg}$ of GBR, (G4) fed with $10 \mathrm{~g} / \mathrm{kg}$ of GBR and (G5) negative control (without colon cancer, unfed with GBR). At 6 weeks of age, the animals in groups 1-4 were injected with AOM intraperitonially (i.p) (15 mg/kg body weight) once weekly for two weeks. At 9 weeks of age, rats in group 2-4 were treated with GBR at $2.5 \mathrm{~g} / \mathrm{kg}, 5 \mathrm{~g} / \mathrm{kg}$ and $10 \mathrm{~g} / \mathrm{kg}$ (weight of GBR (g)/weight of rat $(\mathrm{kg})$ ) by oral administration via gavage once daily for 8 weeks. The animals were fed with commercial basal diet in the form of pellet throughout the experimental period. The GBR free animals were given distilled water (that has been used to dissolve GBR prior to treatment) via gavage throughout the experimental period. Body weight of the rats was recorded weekly until the termination of the study. Upon termination, all ani- 
mal were sacrificed by decapitation under chloroform anesthesia. Colon was removed and cut longitudinally. The colon was washed with phosphate-buffered saline, fixed in $10 \%$ of formalin and stained with hematoxylin and eosin. The total number of ACF and AC per colon was recorded.

\section{Immunohistochemical analysis of $\beta$-catenin and COX-2}

The paraffin embedded sections were heated at $60^{\circ} \mathrm{C}$ for $60 \mathrm{~min}$, deparaffinized in xylene, and rehydrated through graded alcohol at room temperature. Four- $\mu$ m-thick section obtained from whole part of the colon of each rat was treated with $3 \%$ of bovine serum albumin (BSA) for one hour at room temperature to block the non-specific antigen sites, and subsequently incubated with primary antibody for another one hour. The expression of $\beta$ catenin was determined using a monoclonal antibody raised against a peptide corresponding to the $\mathrm{C}$-terminus of mouse $\beta$-catenin (Transduction Laboratories, Lexington, KY) (1:200). COX-2 protein expression was detected by tissue culture supernatant of rabbit IgG (Neomarkers, Fremont, $\mathrm{CA}$ ) raised against a synthetic peptide from $\mathrm{C}$ terminus of rat COX-2 (1:100). All the antibodies were diluted in antibody diluent (LabVision, UK). Streptavidinbiotin complex peroxidase kit (Code No. K0690, LSAB + Kit, DAKO, USA) was used as the secondary antibody. The peroxidase activity was developed by incubating the slides in the substrate 3,3'-diaminobenzidine (DAB) (LabVision, UK). A semi-quantitative scoring system adopted from Rajnakova et al. [28] was used to score the staining by antibody against $\beta$-catenin and COX-2. The immunoreactive score was determined by summing up the extent and intensity of the staining (score = extent+intensity) of five fields, randomly selected from each section of colon per rat. The extent of positive cells was evaluated using the following scale: 0 , no staining of the mucosal epithelial cells in any field; $1+,<25 \%$ of the epithelium stain positive; $2+, 25-50 \%$ stain positive; $3+, 50-75 \%$ stain positive; and $4+,>75 \%$ stain positive. As for the strength of intensity of staining, evaluation was based on the following scale; 0 , no staining of the epithelial cells; $1+$, mild staining; 2+, moderate staining; and 3+, intense staining. The maximum score after summation was 7 and the minimum was 0 .

\section{Statistical analysis}

Difference in ACF and AC incidences among rats fed with GBR was compared by One Way ANOVA, and difference in body weight was analyzed by Two Way ANOVA. Duncan method for multiple comparisons was used to determine the significance among each group. Non-parametric Kruskal-Wallis test and Mann-Whitney $U$-test were used to compare the expression of $\beta$-catenin and COX-2. Correlation between the two proteins was analyzed by Spearman rank correlation test. The mean score was calculated by summation of the extent and intensity of the staining (score = extent+intensity) of five field, randomly selected from each section of colon/rat. The data were presented as mean \pm SEM.

\section{Results}

There was a significant difference $(p<0.05)$ in the body weight between the groups treated with GBR and the control (G1) (data not shown). The effect of GBR on the incidence of ACF is shown in Table 1 and Figure 1. It indicates that there was a significant reduction $(p<0.05)$ in the total number of ACF and AC, and multicrypt of ACF per colon in all the groups treated with GBR (G2, G3 and

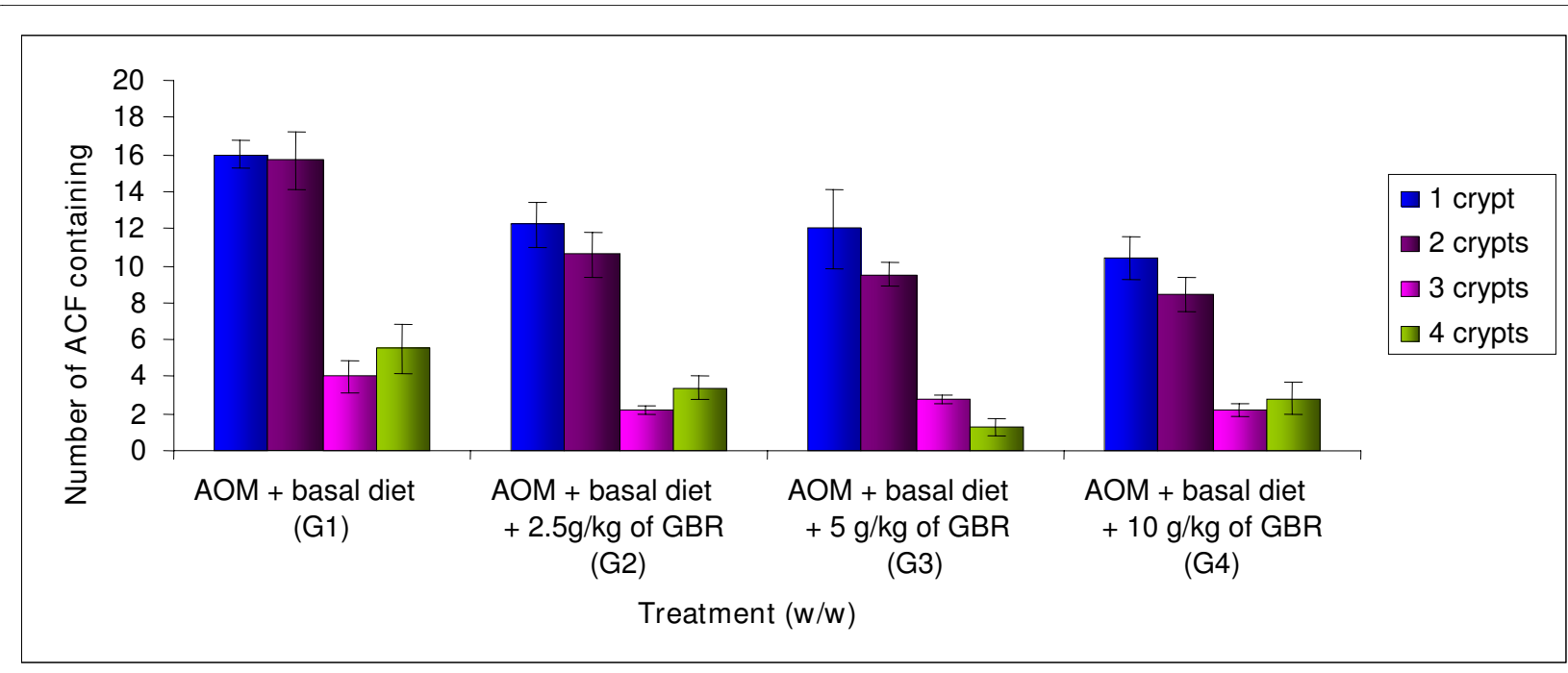

Figure $1 \mathrm{Effect}$ of different percentage of germinated brown rice on number of aberrant crypt foci (ACF) after 8 weeks of treatment. The data were analyzed by using one way ANOVA and the values are expressed as mean \pm S.E.M. $p<0.05$ was considered significant. 
Table 1: Effect of germinated brown rice on AOM-induced ACF formation in male Sprague Dawley rats

\begin{tabular}{|c|c|c|c|c|c|c|}
\hline \multirow[b]{2}{*}{ Treatment } & \multirow[b]{2}{*}{ ACF/colon } & \multicolumn{4}{|c|}{ No. of ACF containing } & \multirow[b]{2}{*}{$\begin{array}{c}\text { Total aberrant } \\
\text { crypt }\end{array}$} \\
\hline & & 1 crypt & 2 crypts & 3 crypts & $\begin{array}{l}4 \text { or more } \\
\text { crypts }\end{array}$ & \\
\hline $\begin{array}{c}\text { AOM + basal diet } \\
\text { (G1) }\end{array}$ & $\begin{array}{r}41.50 \\
\pm 3.008\end{array}$ & $\begin{aligned} & 16.00 \\
\pm & 0.730\end{aligned}$ & $\begin{aligned} & 15.67 \\
\pm & 1.520\end{aligned}$ & $\begin{array}{l}4.00 \\
\pm 0.894\end{array}$ & $\begin{array}{l}5.50 \\
\pm 1.310\end{array}$ & $\begin{array}{r}81.30 \\
\pm 7.745\end{array}$ \\
\hline $\begin{array}{c}\text { AOM + basal diet }+2.5 \mathrm{~g} / \mathrm{kg} \text { of GBR } \\
\text { (G2) }\end{array}$ & $\begin{aligned} & 28.60 \\
\pm & 1.720^{a}\end{aligned}$ & $\begin{array}{r}12.20 \\
\pm 1.241\end{array}$ & $\begin{aligned} & 10.60 \\
\pm & 1.208^{a}\end{aligned}$ & $\begin{array}{l}2.20 \\
\pm \\
0.200\end{array}$ & $\begin{array}{l}3.40 \\
\pm \\
+0.678\end{array}$ & $\begin{aligned} & 53.60 \\
\pm & 3.970^{\mathrm{a}}\end{aligned}$ \\
\hline $\begin{array}{c}\text { AOM + basal diet }+5 \mathrm{~g} / \mathrm{kg} \text { of GBR } \\
\text { (G3) }\end{array}$ & $\begin{aligned} & 25.50 \\
\pm & 2.327^{a}\end{aligned}$ & $\begin{aligned} & 12.00 \\
\pm & 2.160\end{aligned}$ & $\begin{aligned} & 9.50 \\
\pm & 0.646^{a}\end{aligned}$ & $\begin{aligned} & 2.75 \\
\pm & 0.250\end{aligned}$ & $\begin{aligned} & 1.25 \\
\pm & 0.479 a\end{aligned}$ & $\begin{aligned} & 44.25 \\
\pm & 2.750^{\mathrm{a}}\end{aligned}$ \\
\hline $\begin{array}{c}\text { AOM + basal diet }+10 \mathrm{~g} / \mathrm{kg} \text { of GBR } \\
\text { (G4) }\end{array}$ & $\begin{array}{c}24.40 \\
\pm 1.806^{a}\end{array}$ & $\begin{array}{c}10.40 \\
\pm 1.123^{a}\end{array}$ & $\begin{aligned} & 8.40 \\
\pm & 0.927^{a}\end{aligned}$ & $\begin{array}{c}2.20 \\
\pm 0.374\end{array}$ & $\begin{array}{c}2.80 \\
\pm 0.860\end{array}$ & $\begin{array}{c}44.00 \\
\pm 4.159^{a}\end{array}$ \\
\hline
\end{tabular}

Values are expressed as mean \pm SEM. Mean with the a superscript are significant $p<0.05$ as compared to positive control, G1

G4) compared to the control group (G1). Reduction in the total number of ACF and AC, and multicrypt of ACF with increase in the percentage of GBR was observed but yet insignificant.

All tissue samples from G1 showed intense and heterogenous $\beta$-catenin immunoreactivity throughout the colon epithelia (Figure 2). In samples from the treatment groups (G2, G3 and G4), heterogenous expression of $\beta$ catenin was also observed. None of the tissue samples from G5 showed expression of $\beta$-catenin. There was no localization of $\beta$-catenin at cell membrane, cytoplasm and nucleus of the colon epithelial cells. The median scores of $\beta$-catenin expression and mean ranks by Kruskal-Wallis test are shown in Table 2. Comparison between groups by Mann-Whitney U-test showed significant difference $(p=0.0001)$ in the expression of $\beta$ catenin.

The colon epithelia from G1 showed more intense immunoreactivity of COX-2 indicating significant increase $(p=0.0001)$ in the expression of COX-2 com-

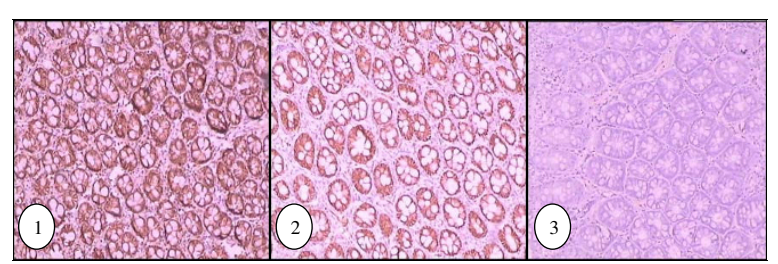

Figure 2 Immunohistochemical staining of positive control (G1) tissue using antibody against $\beta$-catenin. Intense immunoreactivity was present throughout the epithelial cells, in cell membrane and cytoplasm (100x magnification) (1). Immunohistochemical staining of $G 2$ tissue using antibody against $\beta$-catenin showing less intense staining (100x magnification) (2). Immunohistochemical staining of negative control (G5) tissue using antibody against $\beta$-catenin. (100X magnification)(3) pared to the treatment groups (G2, G3 and G4). Weak, diffused and heterogenous expression of COX-2 was observed in the tissue samples from G5 (Figure 3). Localization of COX-2 could be observed at nuclear membrane and cytoplasm of some of the colon epithelial cells. The median scores of COX-2 expression and mean ranks are shown in Table 3. Comparison between groups by MannWhitney U-test showed significant difference $(p=$ 0.0001 ) in the expression of COX-2.

Spearman rank correlation test showed significant positive linear relationship between total $\beta$-catenin and COX-2 score (Spearman's rho $=0.616, p=0.0001$ ).

\section{Discussion}

This study demonstrates that treatment with $2.5 \mathrm{~g} / \mathrm{kg}, 5$ $\mathrm{g} / \mathrm{kg}$ and $10 \mathrm{~g} / \mathrm{kg}$ of GBR (weight of GBR (g)/weight of rat $(\mathrm{kg})$ ) significantly suppressed the total number of ACF, $\mathrm{AC}$ and multicrypt of ACF per colon, yet was insignificant among the GBR-treated groups. It is postulated that the chemopreventive effects of GBR was dose-independent. The ACF was found to consist of 1, 2, 3, 4 or more crypts. It is believed that the number of crypts increases with time due to crypt multiplication or branching [7]. The crypts reproduce themselves by a fission mechanism [29]. However, the number of ACFs correlates poorly with cancer risk. It is the crypt multiplicity that is more predictive of malignant transformation [30]. It has been hypothesized that many ACFs regress and only larger foci or lesions progress to cancer [9]. Therefore, GBR seems to be a potential agent to inhibit the progression of colon cancer since the number of larger foci (4 or more crypts) was found to be significantly less in all groups treated with it compared to the control group (Figure 1).

All tissue samples from G5, which represent the normal colon tissue did not show $\beta$-catenin immunoreactivity 
Table 2: Median scores and mean ranks of $\beta$-catenin expression according to group

\begin{tabular}{|c|c|c|}
\hline Group & Median score* & Mean score \\
\hline $\begin{array}{c}\text { AOM + basal diet } \\
\text { (G1) }\end{array}$ & $6.00^{\mathrm{a}}$ & 300.83 \\
\hline $\begin{array}{c}\text { AOM + basal diet }+2.5 \mathrm{~g} / \mathrm{kg} \text { of GBR } \\
\text { (G2) }\end{array}$ & $5.00^{\mathrm{b}}$ & 223.68 \\
\hline $\begin{array}{c}\text { AOM + basal diet }+5 \mathrm{~g} / \mathrm{kg} \text { of GBR } \\
\text { (G3) }\end{array}$ & $5.00^{\mathrm{b}}$ & 222.94 \\
\hline $\begin{array}{c}\text { AOM + basal diet }+10 \mathrm{~g} / \mathrm{kg} \text { of GBR } \\
(\mathrm{G} 4)\end{array}$ & $4.00^{c}$ & 184.94 \\
\hline Basal diet alone (G5) & $0.00^{d}$ & 39.50 \\
\hline
\end{tabular}

*Median scores with different superscript are significantly different at $\mathrm{p}<0.05$ (Mann-Whitney U-test).

(Figure 2). There was no localization of stain at cell membrane, cytoplasm and nucleus of epithelial cells and goblet cells. This may indicate that the level of $\beta$-catenin in the normal colon mucosa is too low to be detected by this method of immunohistochemistry (IHC). In contrast, previous studies by Hong [31] reported that all the normal adjacent tissue of human colorectal sample showed $\beta$-catenin immunoreactivity in the plasma membrane at cell to cell border, and cytoplasm of the epithelial cells and goblet cells, but no nuclear staining was found. Takahashi et al. [32] also showed localization of $\beta$-catenin at membranes of cell-to-cell borders in normal colon epithelial cells of male F344 rats. The divergence in our staining result may be caused by inter-species and interstrain variation between the Sprague Dawley rats and the other samples (human and other breeds of rats).

In the tissues of positive control group (G1), where colon carcinogenesis was initiated by injection of AOM but no treatment with GBR was given, intense $\beta$-catenin stain (immunoreactivity in the cytoplasm of epithelial cells is prominent) was observed, representing much higher level of $\beta$-catenin (Figure 2). The intensity of the brown stain is variable, where some cells exhibit greater intensity at the cell membrane compared to the cyto-

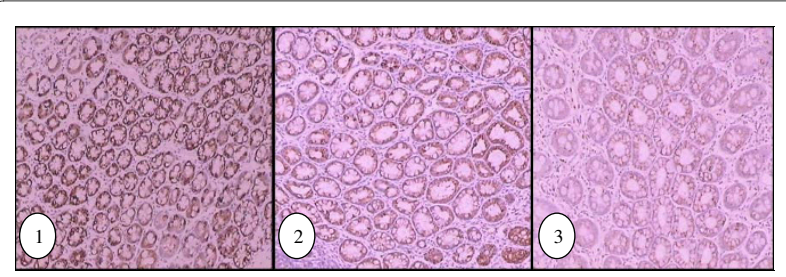

Figure 3 Immunohistochemical staining of positive control (G1) tissue using antibody against COX-2. Immunoreactivity was present throughout the epithelial cells (100× magnification) (1). Immunohistochemical staining of G2 tissue using antibody against COX-2 showing weaker staining compared to G1 (100x magnification) (2).

Immunohistochemical staining of negative control (G5) tissue using antibody against COX-2 (100× magnification)(3). plasm, while other cells lost or have reduced brown stain at the cell membrane, thus appearing that the cytoplasm compartment has more localization of $\beta$-catenin. Overall scoring showed that the epithelial cells of G1, which was shown to have the highest number of aberrant crypt foci (ACF) among all groups (Table 1), has the highest score in the evaluation of immunohistochemical staining of $\beta$ catenin compared to other groups.

According to Goss and Groden [33], $\beta$-catenin binds to the cytoplasmic tail of $\alpha$-catenin and E-cadherin and indirectly to the cytoskeleton. It may dissociate from them and enters cytoplasm as free unbound $\beta$-catenin. Since $\beta$-catenin is an important Wnt signaling pathway activator, its level in the normal tissue is constantly regulated by APC, axin and glycogen synthase kinase- $3 \beta$ (GSK-3 $\beta$ ) complex that targets its rapid degradation in the cytoplasm to prevent translocation of $\beta$-catenin into the nucleus to promote transcription of various target genes [31].

Mutations in $\beta$-catenin, $A P C$, axin and $G S K-3 \beta$ may result in the inability of the complex to phosphorylate $\beta$ catenin, resulting in failure of ubiquitination; whereas $E$ cadherin mutation can cause dissociation of $\beta$-catenin from the complex, releasing free $\beta$-catenin into the cytoplasm. This explains loss or reduced $\beta$-catenin protein at the cell-to-cell borders but an over-expression in the cytoplasm of the G1 tissues.

In the treatment groups (G2, G3, and G4), heterogenous expression of $\beta$-catenin was observed in the cell membrane and cytoplasm compartment. Nevertheless, all the three treatment groups showed significant decrease in $\beta$-catenin expression compared to G1. This indicates that GBR has the potential of reducing the expression of $\beta$-catenin. It is postulated that GBR is a natural chemopreventive agent which acts through pathway involving $\beta$-catenin.

Tissue samples from G5, which represent the normal colon tissue showed some degree of COX-2 immunoreac- 
Table 3: Median scores and mean ranks of COX-2 expression according to group

\begin{tabular}{|c|c|c|}
\hline Group & Median score* & Mean score \\
\hline $\begin{array}{c}\text { AOM + basal diet } \\
\text { (G1) }\end{array}$ & $6.00^{\mathrm{a}}$ & 324.16 \\
\hline $\begin{array}{c}\text { AOM + basal diet }+2.5 \mathrm{~g} / \mathrm{kg} \text { of GBR } \\
\text { (G2) }\end{array}$ & $5.00^{b}$ & 241.72 \\
\hline $\begin{array}{c}\text { AOM + basal diet }+5 \mathrm{~g} / \mathrm{kg} \text { of GBR } \\
\text { (G3) }\end{array}$ & $4.00 c$ & 182.25 \\
\hline $\begin{array}{c}\text { AOM + basal diet }+10 \mathrm{~g} / \mathrm{kg} \text { of GBR } \\
\text { (G4) }\end{array}$ & $4.00^{c}$ & 170.04 \\
\hline Basal diet alone (G5) & $3.00^{\mathrm{d}}$ & 54.15 \\
\hline
\end{tabular}

*Median scores with different superscript are significantly different at $p<0.05$ (Mann-Whitney U-test).

tivity, where the expression of COX-2 was found to be weak, diffused and heterogenous (Figure 3). Lack of expression of COX-2 in tissue samples from G5 indicates that most normal colonic cells were not undergoing inflammation. However there was still a score of 3 as to indicate that inflammation does exist in normal condition but at a very slow rate. COX-2 is known to be an inducible enzyme that plays an important role in induction of pain and inflammation [34]. Localization of COX-2 could be seen mainly at the cytoplasm of colon epithelial cells, and some cells also showed clear nuclear membrane stain. No nuclear staining was observed. Similarly, Tomozawa et al. [35] and Takahashi et al. [36] have also reported COX-2 expression in normal rat colon mucosa using IHC method.

In the tissues of G1, the colon epithelia showed much greater COX-2 immunoreactivity compared to all other groups (Figure 3). The staining was also heterogenous throughout the tissues, mostly in the cytoplasm. No nuclear staining was found. Many studies reported welldocumented observation of COX-2 expression in colonic tumour. For example, Tomozawa et al. [35] and Takahashi et al. [36] have reported positive immunoreactivity in cytoplasm and nuclear membranes of tumour cells. The staining pattern in the treatment groups is similar, but with apparent reduction in both intensity and percentage of positive cell, compared to G1. This shows that GBR prevents colon carcinogenesis by down-regulating the COX-2 expression.

As for the comparison among the treatment groups, there were significant differences $(p=0.0001)$ between G2 and G3, and between G2 and G4. This indicates that the expression of COX-2 decreased with increase in the concentration of GBR. APC, $\beta$-catenin, axin, and GSK-3 $\beta$ mutations can cause increased expression of $\beta$-catenin in the cytoplasm and nucleus of colorectal carcinoma, which leads to Wnt pathway activation. Since COX-2 may be a downstream target of Wnt signaling pathway, $C O X-2$ gene is upregulated and COX-2 expression is increased in tumour cells $[37,38]$.

Spearman rank correlation test showed a statistically positive linear relationship between $\beta$-catenin and COX2 scores. This is in accordance with findings by Kawasaki et al. [39] that showed positive correlation of COX-2 over expression with cytoplasmic $\beta$-catenin expression. Thus, indicating a possible link between COX-2 and the Wnt signaling pathway [40]. COX-2 has been shown to activate $\beta$-catenin through prostaglandin $E 2$ and $G$ proteincoupled receptor EP2 (E prostanoid 2) [41]. A study by Lee and Jeong has shown that $\beta$-catenin stabilizes COX-2 mRNA by interacting with AU-rich elements in a 3' untranslated region [42]. These findings suggest the existence of a positive feedback loop between $\beta$-catenin and COX-2. Therefore, GBR might have suppressed $\beta$-catenin expression through regulation of COX-2 or vice versa. It is also possible that GBR regulates expression of both proteins simultaneously.

This study indicates that GBR possesses good chemopreventive effects, more likely due to the nutritional components that are increasing in content following the process of germination such as phytic acid (IP6), ferulic acid, inositol and dietary fiber [4]. It has been reported that inositol hexaphosphate (IP6) reduced the carcinogen-induced large bowel cancer and inhibited growth of transplanted tumors [43]. However, the mechanism by which IP6 exerts chemopreventive is not completely understood. In general, IP6 is rapidly absorbed by cells and metabolized to lower phosphates and inositol [44]. Both IP6 and its lower phosphates have metal chelating activity and may interfere with tumor formation by suppressing metal catalyzed oxidation of fats. It regulates the cell cycle to block uncontrolled cell division and force malignant cells either to differentiate or to undergo apoptosis [45]. Alternatively, IP6 may block the activity of key enzyme(s) affecting cell proliferation. One enzyme candidate is PI-3kinase which plays a central role in signal 
transduction and cell transformation triggered by growth factor or tumor promoter. IP6 has been reported to inhibit PI-3 kinase activity in vitro [46]. In addition, the antioxidant properties of IP6 may also contribute to its antineoplastic activity [47]. Ferulic acid inhibits the growth of colonic ACF and suppresses the progression of preneoplastic to malignant neoplasia. The suppression of metabolic activation and enhancement of detoxification may become one of the mechanisms for chemopreventive action of ferulic acid [48].

As functional food component, Shamsuddin [44] has reported that inositol plays a role in suppressing tumor formation. Meanwhile, Alabaster [49] has found that the dietary fiber is linked to the prevention of colon carcinogenesis. A high fiber intake result in a high stool bulk, which reduces stool transmit time and thus lowers exposure to potential carcinogens [50].

This findings show that germinated brown rice has chemopreventive properties in rats induced with colon cancer. The administration of $2.5 \mathrm{~g} / \mathrm{kg}, 5 \mathrm{~g} / \mathrm{kg}$ and $10 \mathrm{~g} / \mathrm{kg}$ of GBR (weight of GBR (g)/weight of rat (kg)) significantly reduced the total number of ACF, AC, and multicrypt of $\mathrm{ACF}$, and the expression of $\beta$-catenin and $\mathrm{COX}-2$ compared to the positive control (without GBR). It is suggested that GBR can be a promising dietary intake for prevention of human colon cancer.

\section{Competing interests}

The authors declare that they have no competing interests.

\section{Authors' contributions}

SYL was the chief investigator for this project in planning the study design and contributed to manuscript preparation. NA, HTT and YA took part in planning the study design, scoring of ACF and AC, immunohistochemistry analysis of $\beta$ catenin and Cox-2, statistical analysis and manuscript preparation. AHN processed the GBR. SN and IH assisted in scoring of ACF and AC, and immunohistochemistry analysis of $\beta$-catenin and Cox-2. MS performed the statistical analysis. IM was responsible for funding, study design and GBR supply. All authors read and approved the final manuscript.

\section{Acknowledgements}

This study has been supported by BERNAS Malaysia (Vote No: 63536) and Universiti Putra Malaysia.

\section{Author Details}

'Department of Biomedical Science, Faculty of Medicine and Health Sciences, Universiti Putra Malaysia, 43400 UPM Serdang, Selangor Malaysia,

${ }^{2}$ Department of Nutrition and Dietetics, Faculty of Medicine and Health Sciences, Universiti Putra Malaysia, 43400 UPM Serdang, Selangor Malaysia, 3Department of Pathology, Faculty of Medicine and Health Sciences, Universiti Putra Malaysia, 43400 UPM Serdang, Selangor Malaysia and ${ }^{4}$ Laboratory of Molecular Biomedicine, Institutes of Bioscience, Universiti Putra Malaysia, 43400 UPM Serdang, Selangor Malaysia

Received: 24 April 2009 Accepted: 26 March 2010 Published: 26 March 2010

\section{References}

1. Michael JW: Colon cancer chemoprevention with ginseng and other botanicals. The Korean Academy of Medical Sciences 2001, 16:81-6.

2. Reza H, Soheila K, Martin JJ, Ronis, Jeffery MJ, Thomas MB: Dietary Whey Protein Protects against Azoxymethane-induced Colon Tumors in Male Rats. Cancer Epidemiology Biomarkers and Prevention 2001, 10:555-8.
3. Kayahara H, Tukahara K: Flavor, Health and Nutritional Quality of Pregerminated Brown Rice," presented at 2000 International Chemical Congress of Pacific Basin Societies in Hawaii.

4. Ken'ichi O, Keitaro S, Yuji Y, Takafumi K: Bio-functional components in the processed pre-germinated brown rice by a twin-screw extruder. Journal of Food Composition and Analysis 2004, 18:3003-16.

5. Bird RP: Observation and quantification of aberrant crypts in the murine treated with colon carcinogen: preliminary findings. Cancer Letters 1987, 37:147-51.

6. Pretlow TP, Barrow BJ, Ashton WS, O'Riordan MA, Pretlow TG, Jurcisek JA, Stellato TA: Aberrant crypts: putative preneoplastic foci in human colonic mucosa. Cancer Research 1991, 51:1564-7.

7. McLellan EA, Medline A, Bird RP: Dose response and proliferative characteristics of aberrant crypt foci: putative preneoplastic lesions in rat colon. Carcinogenesis 1991, 12:2093-8.

8. Tetsuji T, Shinichi K, Yasuo T, Motoh O, Shuichi N, Sumio S, Junji K, Katsuhisa K, Katsuhisa K, Hirotsugu M, Yoshiro N: Aberrant crypt foci of the colon as precursors of adenoma and cancer. The New England Journal of Medicine 1998, 339:1277-84.

9. Bird RP: Role of aberrant crypt foci in understanding the pathogenesis of colon cancer. Cancer Lett 1995, 93:55-71.

10. Molenaar M, Wetering M van de, Oosteerwegel M, Peterson-Maduro J, Godsave S, Korinek V, Roose J, Destree O, Clevers H: XTcf-3 transcription factor mediates $\beta$-catenin-induced axis formation in Xenopus embryos. Cell 1996, 86:391-9.

11. Behrens J, von Kries J, Kuhl M, Bruhn L, Wedlich D, Grosschedl R, Birchmeir $W$ : Functional interaction of $\beta$-catenin with the transcription factor LEF-1. Nature 1996, 382:638-42.

12. Young C, Kitamura M, Hardy S, Kitajewski J: Wnt-1 induces growth, cytosolic $\beta$-catenin, and Tcf/Lef transcriptional activation in Rat-1 fibroblasts. Molecular Cell Biology 1998, 18:2474-85.

13. Vogelstein B, Kinzler K: The genetic basic of human cancer McGraw-Hill, Inc. New York; 1998:565-587.

14. Takahashi M, Fukuda K, Sugimura T, Wakabayashi K: $\beta$-catenin is frequently mutated and demonstrates altered cellular location in azoxymethane-induced rat colon tumors. Cancer Research 1998, $58: 42-6$.

15. Morin P, Sparks A, Korinek V, Barker N, Clevers H, Vogelstein B, Kinzler K: Activation of $\beta$-catenin-Tcf signalling in colon cancer by mutation in $\beta$ catenin or APC. Sciences 1997, 275:1787-90.

16. Yamada Y, Yoshimi N, Hirose Y, Kawabata K, Matsunaga K, Shimuzu M, Hara A, Mori H: Frequent $\beta$-catenin gene mutations and accumulations of the protein in the putative preneoplastic lesions lackingmacroscopic aberrant crypt foci appearance, in rat colon carcinogenesis. Cancer Research 2000, 60:3323-7.

17. Tsujii M, DuBois RN: Alterations in cellular adhesion and apoptosis in epithelial cells overexpressing prostaglandin endoperoxide synthetase 2. Cell 1995, 83:493-501

18. Prescott SM, White RL: Self-promotion, intimate connections between APC and prostaglandin H synthase-2. Cell 1996, 87:783-6.

19. Majerus PW: Critical roles in pregnancy and colon cancer. Current Biology 1998, 8:87-9.

20. Smith ML, Hawcroft G, Hull MA: The effect of non-steroidal antiinflammatory drugs on human colorectal cancer cells: evidence of different mechanisms of action. European Journal of Cancer 2000, 36:664-74.

21. Tomazawa S, Tsuno NH, Hatano K, Osada T, Kitayama J, Sunami E, Nita ME, Ishihara S, Yano H, Tsuruo T, Shibata Y, Muto T: Inhibition of haematogenous metastasis of colon cancer in mice by a selective COX2 inhibitor, JTE-522. British Journal of Cancer 1999, 81:1274-9.

22. Mei JM, Hord NG, Winterstein DF, Donald SP, Phang JM: Differential expression of prostaglandin endoperoxide $\mathrm{H}$ synthase- 2 and formation of activated $\beta$-catenin-LEF- 1 transcription complex in mouse colonic epithelial cells contrasting in Apc. Carcinogenesis 1999, 20(4):737-40

23. Williams CE, Coffey RJ, Radhika A, Giardiello FM, Ferrenbach S, DuBois RM: Elevated cycloocygenase-2 levels in min mouse adenomas. Gastroenterology 1996, 111:1134-40.

24. DuBois RN, Radhika A, Reddy BS, Entingh AJ: Increased cyclooxygenase2 levels in carcinogen-induced rat colonic tumors. Gastroenterology 1996, 110:1259-1262. 
25. Kawai N, Tsujii M, Tsuji S: Cyclooxygenases and colon cancer. Prostaglandins and Other Lipid Mediators 2002, 68-69:187-96.

26. Tsujii M, Kawano S, Tsuji S, Sawaoka H, Hori M, DuBois RN: Cyclooxygenase regulates angiogenesis induced by colon cancer cells. Cell 1998, 93:705-16.

27. FAO Rice Conference: Marketing value-added rice products in Japan: Germinated Brown Rice and rice bread. FAO Rice Conference 04/CRS.7 2004

28. Rajnakova A, Moochhala S, Goh PMY, Ngoi SS: Expression of nitric oxide synthase, cyclooxygenase, and $\mathrm{p} 53$ in different stages of human gastric cancer. Cancer Letters 2001, 172(2):177-85.

29. Maskens AP, Dujardin LR: Kinetics of tissue proliferation in colorectal mucosa during post-natal growth. Cell Tissue Kinetic 1981, 14:467-77.

30. Jen J, Powell SM, Papadopoulus N: Molecular determinants of dysplasia in colorectal lesions. Cancer Research 1994, 54:5523-6.

31. Hong SK: A pilot study on adenomatous polyposis coli, beta-catenin cyclooxygenase-2 and inducible nitric oxide synthase expression in colorectal carcinoma. Bac. Thesis, Universiti Putra Malaysia; 2001.

32. Takahashi M, Fukuda K, Sugimura T, Wakabayashi K: $\beta$-catenin is frequently mutated and demonstrates altered cellular location in azoxymethane-induced rat colon tumors. Cancer Research 1998, $58: 42-6$

33. Goss KH, Groden J: Biology of the adenomatous polyposis coli tumour suppressor. Journal of Clinical Oncology 2000, 18(9):1967-79.

34. Asma AK, Michael I, Hsiu-Ying TY, Raymond AD: Expression of COX-1 and COX-2 in a Clinical Model of Acute Inflammation. The Journal of Pain 2007, 8(4):349-354

35. Tomozawa S, Tsuno NH, Sunami E, Hatano K, Kitayama J, Osada T, Saito S, Tsuruo T, Shibata Y, Nagawa H: Cyclooxygenase-2 overexpression correlates with tumour recurrence, especially haematogenous metastasis, of colorectal cancer. British Journal of Cancer 2000, 83:324-8.

36. Takahashi M, Mutoh M, Kawamori T, Sugimura T, Wakabayashi K: Altered expression of $\beta$-catenin, inducible nitric oxide synthase and cyclooxgenase- 2 in azoxymethane-induced rat colon carcinogenesis. Carcinogenesis 2000, 21(7):1319-27.

37. Mei JM, Hord NG, Winterstein DF, Donald SP, Phang JM: Differential expression of prostaglandin endoperoxide $\mathrm{H}$ synthase- 2 and formation of activated $\beta$-catenin-LEF-1 transcription complex in mouse colonic epithelial cells contrasting in Apc. Carcinogenesis 1999, 20(4):737-40.

38. Dimberg J, Hugander A, Sirsjö A, Söderkvist P: Enhanced expression of cyclooxgenase- 2 and nuclear $\beta$-catenin are related to mutations in the APC gene in human colorectal cancer. Anticancer Research 2001, 20:911-6.

39. Kawasaki T, Nosho K, Ohnishi M, Suemoto Y, Kirkner GJ, Dehari R, Meyerhardt JA, Fuchs CS, Ogino S: Correlation of $\beta$-Catenin Localization with Cyclooxygenase-2 Expression and CpG Island Methylator Phenotype (CIMP) in Colorectal Cancer. Neoplasia 2007, 9(7):569-577.

40. Buchanan FG, DuBois RN: Connecting COX-2 and Wnt in cancer. Cancer Cell 2006, 9:6-8.

41. Castellone MD, Teramoto H, Williams BO, Druey KM, Gutkind JS: Prostaglandin E2 promotes colon cancer cell growth through a Gsaxin- $\mu$ catenin signaling axis. Science 2005, 310:1504-10.

42. Lee HK, Jeong S: Beta-catenin stabilizes cyclooxygenase- 2 mRNA by interacting with AU-rich elements of 3'-UTR. Nucleic Acids Research 2006, 34:5705-14

43. Jariwalla RJ, Sabin R, Lawson S, Bloch DA, Prender M, Andrews V, Herman ZS: Effect of dietary phytic acid (phytate) on the incidence and growth rate of tumors promoted in Fisher rats by a magnesium supplements. Nutrition Research 1998, 8:813-27.

44. Shamsuddin AM, Ullah A, Chakravathy A: Inositol and inositol hexaphosphate suppresses cell proliferation and tumor formation in CD-1 mice. Carcinogenesis 1989, 10:1461-3.

45. Vucenic I, Shamsuddin AM: Cancer inhibition by inositol hexaphosphate (IP6) and inositol: From laboratory to clinic. The American Society for Nutritional Sciences 2003, 133:3778-84.

46. Dong Z, Huang C, Ma WY: PI-3 in signal transduction, cell transformation, and as a target for chemoprevention of cancer. Anticancer Research 1999, 19:3743-7.

47. Verghese M, Rao DR, Chawan CB, Walker LT, Shackeleford L: Anticarcinogenic effects of phytic acid (IP6): apoptosis as a possible mechanism of action. Lebensmittel-Wissencheft and Technologie 2006 39:1093-1098.

48. Kawabata K, Yamamoto T, Hara A, Shimizu M, Yamada Y, Matsugana K, Tanaka T. Mori H: Modifying effects of ferulic acid on azoxymethaneinduced colon carcinogenesis in F344 rats. Cancer Letters 2000, 157:15-21.

49. Alabaster ZT, Shivapurkar N: Dietary fiber and the chemopreventive modulation of colon carcinogenesis. Mutation Research 1996, 350:185-97.

50. Burkitt DP: Related diseases: related cause? Lancet 1969, 2:1229-1231.

doi: 10.1186/1475-2891-9-16

Cite this article as: Latifah et al., Germinated brown rice (GBR) reduces the incidence of aberrant crypt foci with the involvement of ?-catenin and COX-2 in azoxymethane-induced colon cancer in rats Nutrition Journal 2010, 9:16

\section{Submit your next manuscript to BioMed Central and take full advantage of:}

- Convenient online submission

- Thorough peer review

- No space constraints or color figure charges

- Immediate publication on acceptance

- Inclusion in PubMed, CAS, Scopus and Google Scholar

- Research which is freely available for redistribution

Submit your manuscript at www.biomedcentral.com/submit
C Biomed Central 